海老澤 徹

（元京都大学原子炉実験所）

\title{
Neutron Optics and the Instrumentations
}

Toru Ebisawa

ex-Research Reactor Institute of Kyoto University

\section{$000 \bullet \bullet \bullet \bullet \bullet \bullet \bullet \bullet \bullet \bullet ० ० 000000 \bullet \bullet \bullet \bullet$}

\begin{abstract}
My study on neutron optics started in 1970 when I got the information of the neutron mirrors and the neutron guide tube in the Technical University of Munich. I, however, had limited my neutron optics on the neutron mirrors and the neutron guide tubes until 1985. Since 1990, I have challenged to the neutron spin interferometry together with my collaborators, which include new young physicists too.
\end{abstract}

Keywords: neutron optics, neutron mirror, neutron spin interferometry

1.はじめに

この度は，中性子科学会より，功績賞を頂き感 謝しております。私は人生の多くの時間を中性子 を用いた多くの研究者（中性子光学の専門家に限 定されない）と共に中性子光学研究に従事してき ましたが，これらの共同作業は大変興味深く，ま た，楽しいものでした。あらためて感謝したいと 思います.

私の関わった中性子光学研究は，大きく 2 期に 分けることが出来ます.

第一期は，1970 年から 1985 年までの期間，京 大原子炉実験所（京大炉）で行われた中性子光学 研究です.

第二期は，それ以降の中性子スピン干渉現象を 中心としたより範囲の広い中性子光学研究です. この第二期の研究は, 原子力研究開発機構(原研) 3 号炉 C3-1-2 ポート, 及び, 京大原子炉 CNS ビ ームポートを用いて行いました。

\section{2. 京大炉における中性子光学}

2.1 中性子導管との出会い

私が京大炉に入所したのは，京大原子炉が臨界 になった 1964 年であった。 その当時, 私に課せら れた職務は, 中性子のサブサーマル領域の単色ビ 一ムを得るための中性子メカニカルモノクロメー ターの運転，改良，並びに，原子核構造研究者の データ取得を支援することであった。この装置の 目的は，共鳴領域中性子の吸収による核構造の研 究であったが，中性子強度が弱いこと，興味ある 原子核構造研究のテーマがなかなか見つからない 等の困難を当初から抱えていた。そのような状況
に苦慮していた私にとって，1969年の秋に，ミュ ンヘン工科大学において既に始まっていた optics を基礎にした中性子導管に関連する文献に出会っ たのは，偶然の幸運であった，当時は現在のよう に便利な文献検索システムもなく，科学雑誌も各 国の言語で書かれるのが一般的であった（各国の 科学雑誌が英語に統一されるのは 1970 年であっ た). 中性子導管に関する文献との出会いも偶然で あったが，私は，この時，中性子導管製作の基礎 となった中性子光学を専門にすることを決意した.

\section{2 京大炉中性子導管の設置（1970～1972）}

ミュンヘン工科大学における中性子導管の製作 法に関する主要な文献は, 1970 年の初めまでには ほぼ入手出来た. また, 72 年に運転を開始する ILL の中性子導管群計画に関する資料も入手した。こ れらの文献に対しては，私の上司である岡本朴部 門長も大いに興味を示した.

部門長の主導のもとに，中性子導管製作法のバ イブルとも言える Alefeld. B による文献を中心に してゼミが直ちに組織された。 ゼミの対象は, 部 門員全員と所長（柴田俊一教）である. 同時に, 中性子導管を設置するプロジェクトの立ち上げと 導管設置のために科学研究費の要求（1970 年）が 行われた。

科研費は翌 71 年には認められ, 中性子導管設置 のための準備作業が開始された.中性子導管の構 造の決定と製作の方法, 中性子ミラー製作の依頼 先，原子炬に設置するための実験ポートの改造や 中性子導管遮蔽，あるいは，原子炬格納容器に隣 接する中性子測定室建設等の準備作業が開始され 
た。 中性子ミラーはフロートガラス面にスパッタ 一された $\mathrm{Ni}$ 薄膜が用いられた。この $\mathrm{Ni}$ 中性子ミ ラーは日本板硝子の研究所で作成した. この当時, ガラスメーカーは， 1 メートル四方の大きなフロ 一トガラス面にスパッター法で金属薄膜を作成す る技術を既に有していた。

E-3 実験孔に中性子導管を設置する作業は，73 年 12 月に完了した[1]. この中性子導管は現在で も利用されている。

2.3 京大炉における中性子ミラー反射率測定の開 始

京大炉における中性子ミラー反射率の測定の開 始は，中性子導管製作と平行して行われた。すな わち, 導管用の $\mathrm{Ni}$ 全反射ミラー製作時に，以下の ような中性子ミラーを日本板硝子(株)に依頼して 試作した。 $\mathrm{Ni}$ 全反射ミラー, $\mathrm{Ni}$ 薄膜， $\mathrm{Ni}-\mathrm{Ti}$ の 2 層薄膜， $\mathrm{Co}-\mathrm{Fe}$ 合金薄膜等である。これらの中性 子ミラーに対してチョッパーTOF 法による反射率 測定が行われた。測定結果は，蒸着薄膜をその中 性子散乱長から評価される 1 次元井戸型ポテンシ ヤルで近似し，入射中性子を平面波で近似寸ると， 中性子の反射特性が良く再現されることが実証さ れた. これが京大炉における中性子光学の始まり であった。この研究結果を論文にして投稿する段 階で, 同様の主旨の論文がミュンヘン工科大学の A. Steyerl 教授によって直前に発表されているの を発見し，投稿を断念した。後に触れるが，私の 研究の進路を変える切っ掛けは, 後の彼との研究 交流によるものである.

2.4 中性子ミラー製作の開始と中性子光学の進展 (1974 1978)

（1）京大炉において，中性子多層膜ミラーを製作 するための真空蒸着装置の準備をはじめたのは, 中性子導管実験室の整備がほぼ終了した 75 年の 初めであった。新しい研究をスタートするに当た って, 実験所内で使用されていない真空蒸着装置 を探し出し，それを改造して多層膜ミラーを試作 する方法を選択した。表面積が $15 \mathrm{~cm} \times 7 \mathrm{~cm}$ のフロ 一トガラスを 2 枚セットして多層膜ミラーを蒸着 できる装置を何とか完成したのが，1976 年の初め であった。ちなみに，この装置の蒸着時の真空度 は, diffusion pumpの性能が良くなく, $1 \times 10^{-5}$ Torr と通常のものより 1 桁悪かった。

(2) この間，1974 年には，B.P. Schoenborn 等によ る多層膜モノクロメーターの論文，及び，1976 年 には F. Mezei によるスーパーミラーの論文等が 出版された.これらの多層膜ミラーのアイデアは, 中性子光学研究の将来性を高めるものであった.

(3) 直ちに, 多層膜モノクロメーターやスーパー ミラー, あるいは，中性子偏極用の磁気ミラー等 の試作を開始した。若干の試行錯誤はあったが， 1976 年の秋には, 試作した多層膜ミラーの反射率 は, 当時の実用的なレベルに到達していた.また， 多層膜ミラーの反射率も前述の方法を用いて評価
すると，複雑な構造のものでも測定された反射率 は良い近似で再現されることが示された[2,3]. こ れらの研究結果は, 実用的な中性子ミラーの開発 に世界で最初に成功したことを示していた。この 当時, 反射率の測定, データ解析や論文作成等を 共同で行ったメンバーは，阿知波紀郎氏と山田修 作氏を加えた 3 人で主として行われた. 阿知波氏 は, 磁性体の研究者であり, 後に所属も九大に変 わったが，その後もずっと密接な共同研究者であ った.

(4) この成功を受けて, 1980 年春には市販されて いる 標準型の diffusion pump をもつ蒸着装置を部 門長の配慮により購入することができた。この装 置では, ベルジャーの容積も大きく, 蒸着可能な 試料の面積も格段に大きくなったこと, 当時発売 されていた 8 ビットパソコンを利用して電子銃に よる自動蒸着が可能になったこと等, 多層膜成膜 装置としての性能は飛躍的に向上した, しかし, この装置で作成した初期の多層膜ミラーの中性子 反射率は，意外にも実用性を持たない低いもので あった. 新旧の装置の違いとして考えられたのは, 真空度の違いであった。すなわち新しい装置の真 空度は $1 \times 10^{-6}$ Torr であり, 最初の装置より一桁良 いことであった。 そこで，リークバルブを開けて 真空度を一桁悪くすると, 作成された中性子ミラ 一の反射率は 格段に改善され, 前述の真空度の悪 い蒸着装置による反射率が再現された.すなわち, 多層膜生成時における真空度は, 偶然にも $1 \times 10^{-5}$ Torr 程度が最適であったわけである. 酸素の存在 による蒸着膜の酸化の程度によるものと推定され る.

2.5 KUR におけるその後の中性子光学研究

以下に新しい蒸着装置の導入以降における KUR 中性子光学の経過について簡潔に述べる.

(1) パーマロイー ゲルマニウム磁気多層膜ミラー の開発

パーマロイは偏極中性子ビームを得るための磁 性材料，核的材料として優れている，一方，ゲル マニウムは結晶化しにくい元素として非磁性材料 として優れている.

（2）中性子波による巨視的共鳴現象の研究 (1979)

中性子波動はある種のポテンシャルを通過する 際に共鳴現象が生じると予測されるポテンシャル が存在する. そのようなポテンシャルを真空蒸着 装置で作成し，京大炉 E-3 導管に設置されている 反射率計によって上記現象が起こることを実際に 実証した。この実験は A. Steyerl 教授が 1979 年に 半年間, 京大炉に滞在した際に彼の提案により行 われた[4].

(3) 大面積スーパーミラー製作法の開発とスーパ 一ミラー中性子導管の世界最初の設置

上記新規導入された蒸着装置を用いると, $30 \mathrm{~cm}$ $\times 10 \mathrm{~cm}$ の面積のフロートガラス 8 枚に $3 \mathrm{Q}_{\mathrm{c}}$ のスー パーミラーを一度に蒝着することが可能である. 1984 年には世界で最初の熱中性子導管が KUR の 
B4-実験孔に設置された。この導管もまた，現在で も使用されている.

（4）中性子ミラーの製作法は1980 年代の後半から, マグネトロンスパッター法，ずっと遅れるがイオ ンビームスパッター法へと進化した。特に，21 世 紀に入ってから京大炉や原研に導入されたイオン ビームスパッター法によって達成された精密中性 子光学のレベルの高さには，隔世の感がある.

(5) 京大炉冷中性子源実験施設に中性子導管を設 置（1988～1990）

CN2，CN3 ポート用に 2 本のスーパーミラー冷 中性子導管を設置すると共に, CN1 ポートに干渉 計開発用の簡易型冷中性子導管を設置した.

(6) ILL 滞在における貴重な経験（1986）

1986 年はチェルノブイリ事故のあつた年であ るが，1 年間 ILL に滞在し, Prof. A. Steyerl 氏によ つて開発，製作された UCN neutron microscope の 特性測定を ILLの炉室 2 階にある UCN, VCN beam port で行った[5]. その場所で行われていた他の実 験は, neutron EDM の測定, magnetic VCN bottle を用いた中性子寿命の測定，あるいは，中性子電 荷の上限測定等，日本では考えられない実験が多 大の脳力と労力を使って行われていた．私自身も そこで 1 年間どんな物理に役立つのか良くわから ない実験を続けながら，私も日本に帰ったら，こ れまで考えてこなかった分野に挑戦してみたいと 切に思っていた。

3 長波長中性子干渉計の開発と研究（1990 以降） 3.1 新しい研究グループの結成と科研費重点領域 研究による財政的支援の決定（1990）

1980 年代の後半には，日本においても KEK 等 の研究会において中性子干渉計を用いた量子力学 的観測問題が集中的に議論されるようになってい た。そのような議論の中で，今からスタートする なら既に 10 年の歴史がある Si 完全単結晶を用い た干渉計の開発ではなく，従来のものと異なった 新しい原理による長波長中性子干渉計を開発し, 新しい干渉現象の観測を目標にすべきだと考えた。 幸いにも，そのような考えの，20才代の若い人達 と新しい研究グループを 1990 年に立ち上げた. そ の時のメンバーは，大竹淑恵氏，田崎誠司氏，舟 橋春彦氏，海老澤徹の 4 名であった。

それと時を同じくして政池明氏（京大教授）を 総括責任者とする文部省科学研究費重点領域研究

（No. 4244103，1991 年～1995 年）に研究課題” 多層膜中性子干渉計の開発と干渉現象の研究” と いうテーマで参加することができて，研究計画を 実行するための予算的な裏付けを得ることもでき た。

3.2 原研 3 号炉，第一世代 C3-1-2 中性子光学ポー 卜の設置（1991～199）

長波長中性子干涉計を開発し，開発後の研究を 推進するためには, 中性子強度が出来るだけ大き な専用の長波長中性子ビームポートは不可欠に重 要である. 京大原子炉 CNS のビームポートと原研
3 号炉のビームポートを比較すると, 中性子強度 で 10 倍の違いと CNS 運転の利用時間で 5 倍以上 違い，利用可能な中性子数では，50 倍以上の違い になる. そのため, 将来にわたる研究推進のため には，原研 3 号炉にビームポートを確保すること は極めて重要な条件であった。そこで上記研究目 的のために C3-1-2 ポートの利用承認を物性研に 要請した。当時の物性研施設長の山田安定先生の 御決断により私たちの要請は受け入れられたので すが，その際，吉沢先生，加倉井先生等の御賛同 も含めて忘れられないことであった。

3.3 第一世代 C3-1-2 ポートの設置（1993 年）と利 用開始

C3-1-2 ポートを利用するためには，実験スペー スを確保するために中性子ビームを約 24 度程度 曲げる必要がある. 当時の中性子ミラーの性能を 考慮して，面間隔（2d）が $100 \AA$ で反射率 $90 \%$ の 多層膜中性子モノクロメーターを 4 枚用い，4 回 の連続反射のシステムを設置することにより， $12.5 \AA$ の波長の中性子を約 24 度曲げて取り出すこ とが出来た。C3-1-2 ポートの設置作業は, 大竹淑 恵氏，田崎誠司氏，舟橋春彦氏，海老澤徹の 4 名 によって主に行われた。 その際, 既設のC3-1-1 ポ 一トとの干渉があり，様々な困難に遭遇したが， 物性研川村さんの適切なご指導により無事切り抜 けることができた。

C3-1-2 ポートが利用できるようになった段階で， 阿知波紀郎氏（(九大教授），河合武氏（京大炉教 授), 日野正裕氏（九大博士課程）等も参加した. 高分子薄膜を対象とした反射率計としての利用で は，鳥飼直也さん（現三重大准教授）や金谷利治 さん（現中性子科学会長）等，高分子の専門家に お世話をお願いした。

\subsection{C3-1-2 ポートの大改造（2001 年，2002 年）}

C3-1-2 ポートを大改造する提案は，私の停年が 1 年後に迫った 2001 年の 2 月に原研の鈴木淳市さ んからあった。直ちに，原研の鈴木淳市氏，曾山 和彦氏，物性研の川村氏，京大原子炉の田崎誠司 氏，海老澤徹の 5 人のワーキンググループが組織 され，2002 年の春に完成した[6]. その結果, 従来 24 度曲げられた単色ビーム 1 本だった C3-1-2 ポ 一トは，14.5 度 (白色), 24 度 (白色), 35 度（単 色）と曲げられた 3 本のビームポートによる $3 つ$ の実験施設に大幅に改善された. Fig. 1 は，新た に誕生した 3 本の導管から得られた中性子のビー ム強度である[6].

この C3-1-2 の大改造は, 中性子施設の利用効率 を大幅に上げた画期的なプロジェクドであったが， 改造に伴う作業には大きな困難も幾つかあった。

その第一は，ガイド増設作業のために小角散乱 用の中性子速度選別機を一時的に撤去しなければ ならなかったこと, 既設の C3-1 ポートとの干渉 


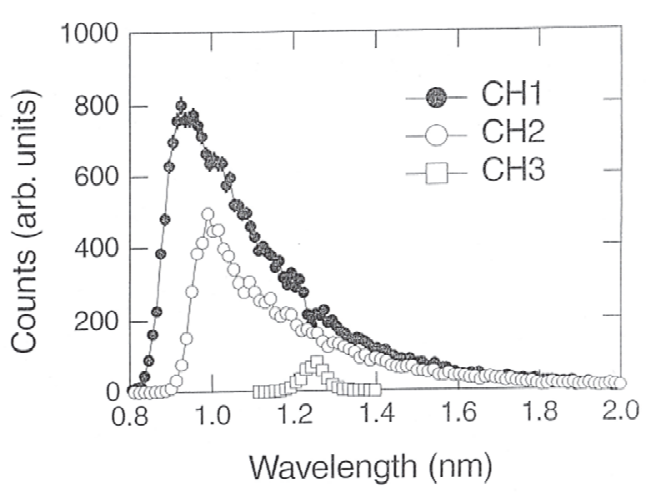

Fig.1 Neutron spectra in the three new ports.

を避ける必要があったこと，放射化している遮蔽 体に 3 本のビームを通すための加工等，多くの厳 しい困難に直面した。また，新ポートの性能を左 右する $3 \mathrm{Q}_{\mathrm{c}}$ のスーパーミラーの入手もピンポイン トのタイミングで幸運にも入手出来た。これらの 困難な作業は，鈴木淳市さん，曽山さん，川村さ 几 3 人の専門性によって解決された。停年を直前 にしたこの時の経験も，私にとって忘れることの ない貴重な体験であった。

\section{5 独創的な様々な冷中性子干涉計の開発}

1991 年から着手した Mach-Zehnder 型冷中性子 干渉計の開発には成功しなかった。しかし，3 年 間にわたる干渉計開発研究の経験は，干渉計の成 立する物理的条件に関する様々な知見をもたらし た[7]. その経験に基づいて 95 年以降，様々な冷 中性子 (多層膜) 干渉計が開発された。それら干 渉計の特性については下記の代表的な文献を参照 されたい.

(a) 多層膜冷中性子干渉計に関する舟橋，北口等 による論文 $[8,9]$.

(b) 多層膜スピンスプリッターを用いた干渉計に 関する田崎, 海老澤等らの論文 $[10,11,12]$.

(c) 共鳴フリッパーを用いた冷中性子干渉計に関 する論文, 山崎大, 丸山龍治等の論文 $[13,14]$.

(d) 共鳴 flipper を用いたスピンエコー法の開発に 関する日野, 北口, 川端等の論文[15].

4 磁場の強度に依存しないスピンエコー法に関 する一つの提案

4.1 磁場中における中性子スピンの量子力学的取 り扱い

スピン $1 / 2$ の粒子である中性子は，量子力学的 には，磁場中，B，では土1/2 の值しか取り得ず， precession という概念は成立しない. 比較的大きな 值をもつ magnetic moment を取り扱う磁性体研究 では，古典的取り扱いが良い近似になるが，中性 子スピンの場合には下記に示されるように，量子 力学的取り扱いが不可欠である. (a) 偏極中性子ビームは, $\pi / 2$ フリッパーによって $\pm 1 / 2$ スピンをもつ 2 つの状態の重㸚合わせ状態 になる. それら中性子の potential energy は, 一（士 $\mu_{\mathrm{n}}$ ・B）によって与えられる。十スピン中性子は 速度が速く, 一スピン中性子は遅いので, 両者は 空間的に分離する。ここで， $\mu_{\mathrm{n}}$ は中性子の magnetic moment である.

(b) $\pm 1 / 2$ スピン中性子の磁場中における運動を 考える. 両者の空間的な分離による経路差を D と 寸ると位相差, $\phi$, は次式で与えられる[11].

$$
\phi=2 \pi \mathrm{D} \mathrm{n} / \lambda
$$

ここで，入は中性子波長であり， $\mathrm{n}$ は経路媒質の 屈折率であり, 空気中では近似的に 1 である.

4.2 Multilayer Spin Splitter(MSS)の構造とスピンの 量子回転

(a) MSS とはFig. 2 に示される構造を持つ複合中 性子ミラーである。 それは，平面性の良いシリコ ン基板上に中性子を反射寸る非磁性の多層膜ミラ 一を最初に成膜し，ゲルマニウム（Ge）の厚い Gap 層を挟んで，表面側の十スピン中性子を反射 する磁気ミラーから構成される.

(b) 偏極中性子は $\pi / 2$ フリッパーによって十スピ ンとースピンの重祇合わせ状態になるが，そのよ うな中性子が MSS に入射すると, 十スピン成分は MSS の表面で反射し，一スピン成分は Ge のギャ ップ層を透過して, その奥の Non Magnetic Mirror により反射される. その結果, Fig. 2 に示される ように，2つの反射ビーム成分は中性子の進行方 向及びその直角方向に空間的に分離する.

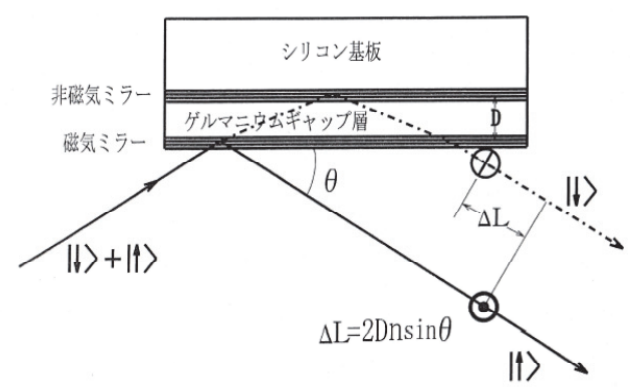

Fig.2 Structure and principle of a multilayer spin splitter(MSS).

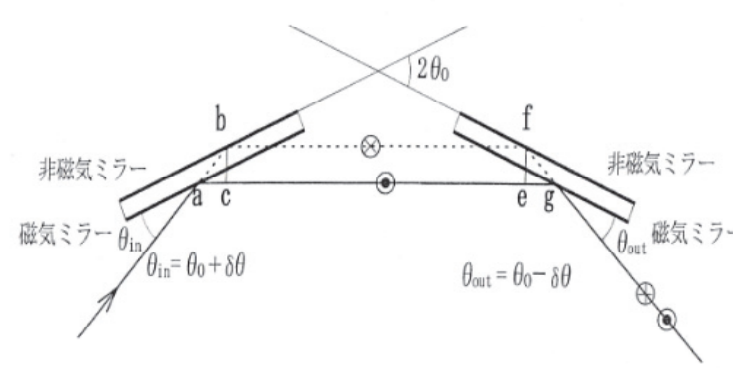

Fig.3 Structure and function of a Double MSS 
4.3 上記，同一特性の 2 つの MSS が Fig. 3 に示さ れるように $2 \theta$ 。の交差角で配置された double MMS の体系（DMMS）を考える.

土の重ね合わせ状態にある中性子がこの体系に 入射するとき, 十スピン成分は左側の磁気ミラー の表面で反射し，一スピン成分は裏側の非磁気ミ ラーで反射される，右側の磁気ミラーでも同様の 反射が生じるので, 土のスピン分波間には位相差, $\phi$ が生じる。この位相差は, Ge 層内の屈折率を 無視すると， $\phi$ は下式によって与えられる[11].

$$
\begin{aligned}
\phi & =\{(\mathrm{ab}-\mathrm{ac})+(\text { fg-eg })\} / \lambda \\
& =(4 \pi \mathrm{D} \sin (\theta)) / \lambda
\end{aligned}
$$

ここで， $\theta$ は MSS へ入射角である.

このスピンエコー装置の配置例は Fig. 4 によっ て示される。また，そのスピンエコー装置として の予測性能は Table 1 に示される.

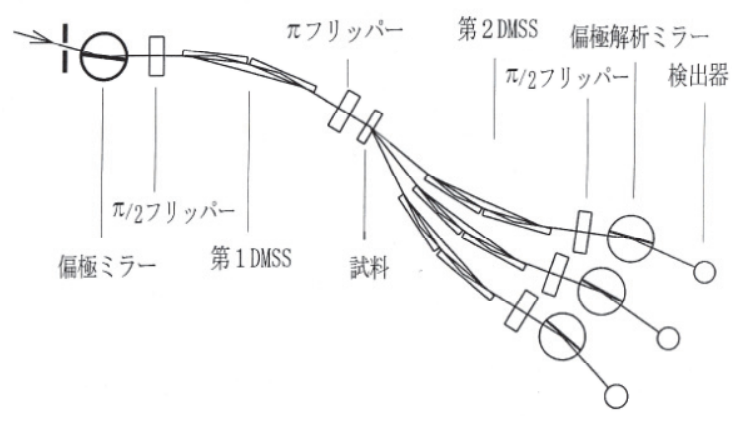

Fig.4 An arrangement of a neutron phase spin echo spectrometer using a pair of DMSSs.

Table 1 Neutron spin rotation by DMSS using Eq. (2),

\begin{tabular}{|c|c|c|c|}
\hline 波長 (nm) & 0.6 & 0.12 & 0.24 \\
\hline \multicolumn{4}{|l|}{ ギャップ厚 : $1 \mu \mathrm{m}$} \\
\hline 回転数 & 133 & 133 & 133 \\
\hline エネルギー分解能 $(\mu \mathrm{eV})$ & 35 & 8.6 & 2.2 \\
\hline$\tau_{n s e}($ nsec $)$ & 0.12 & 0.49 & 1.9 \\
\hline \multicolumn{4}{|l|}{ ギャップ厚：10 $\mu \mathrm{m}$} \\
\hline 回転数 & 1330 & 1330 & 1330 \\
\hline エネルギー分解能 $(\mu \mathrm{eV})$ & 3.5 & 0.86 & 0.22 \\
\hline$\tau_{n s e}($ nsec $)$ & 1.2 & 4.9 & 19 \\
\hline \multicolumn{4}{|l|}{ ギャップ厚: $100 \mu \mathrm{m}$} \\
\hline 回転数 & 13300 & 13300 & 13300 \\
\hline エネルギー分解能 $(\mu \mathrm{eV})$ & 0.35 & 0.086 & 0.022 \\
\hline$\tau_{\text {nse }}($ nsec $)$ & 12.0 & 49 & 190 \\
\hline
\end{tabular}
energy resolution and $\tau_{\text {nse }}[11]$.

4.4 Table.1 に示されるように，このタイプのスピ ンエコー法が実用化するためには，平行度の良い ギャップ層の間隔は，10ミクロン以上という条件 が達成される必要がある。しかし，この要求の実 現は容易ではなく, 2002 年に行われた田崎等の実 験が最後であった。
4.5 その後の中性子光学の発展は 2 つの方法で従 来の技術的な壁を越える可能性を示唆している. その方法の一つは, 京大炉及び原研で開発された 精密イオンビームスパッタリング法を用いて Ge ギャップ層の平行性を精度良く達成する方法であ る[16]. もう一つの可能性は, 北口等によって行 われた平行エタロンを利用する方法である $[8,9]$. 後者では, 約 10 ミクロンのギャップ層に対して干 渉パターンを観測している.

\section{5.おおりに}

1970 年からスタートした京大原子炬実験所に おける中性子導管の設置が私の中性子光学研究の 出発点です. その研究を主導したのは故岡本朴氏 （元京大炉教授）です。また，1979年から始まっ た A. Steyerl 教授との交流は，私が neutron spin interferometry に進む契機にもなった. 1987 年から 2002 年の定年退職まで私のスピン光学の開発テ ストは京大炉の CNS ポートで行われた. その施設 の設置と運転，管理を責任者として行ったのは， 宇津呂雄彦氏（元京大炉教授）, 河合武氏（元京大 炉教授）である. 1991 年以降の原研 3 号炉 C3-1-2 ポートにおける研究活動を可能にしたのは, 政池 明氏（元京大理学部教授）を総括責任者とする重 点領域研究（1991 年～1995 年）に加わることが出 来たことです. また，C3-1-2 ポートを中性子光学 研究用ポートとして認めて頂いたのは, 山田安定 氏（元東大物性研教授, 中性子散乱施設長）の決 断です. 諸先生方に深謝致します.ここに記載す ることは不可能ですので，氏名は省略しますが， 直接的，間接的を問わず，多くの研究仲間と長期 にわたる共同研究生活を楽しく過ごすことが出来 ました。心からの感謝を表します。私に残された 時間は，長くはありませんが，機会があれば，今 後とも宜しくお願いします.

なお, 図, 表は原著でなく, ”中性子スピン光学, 阿知波紀郎編著”より，引用した。

参考文献

[1] 岡本朴他, KUR 中性子導管, (1974).

[2] T. Ebisawa, N. Achiwa, et al., Journal of Sci \& Tech. 16, 647(1979).

[3] S. Yamada, T. Ebisawa, N. Achiwa, et al., Annu. Rep. Res. Reactor Inst. Kyoto Univ., 11, 8(1979).

[4] A. Steyerl, T. Ebisawa, M. Utsuro, Z. Phys. B-Condense Matter 41, 283-286(1981).

[5] A. Steyerl, W. Drexel, T. Ebisawa, et al. Revue Phys. Appl. 23 (1988) 171-180. [6] J. Suzuki, S. Tasaki, K. Soyama, T. Ebisawa, Appl. Phys. A 74 [Suppl.], S308-S310(2002).

[7] T. Ebisawa, S. Tasaki, Y. Otake, H. Funahashi, et al., NIM A, 334(1994) 594-606.

[8] H. Funahashi, T. Ebisawa, T. Haseyama, M. Hino, A. Masaike, Y. Otake, S.Tasaki, Phys. Rev. A, Vol 54. 649-651. 
[9] M. Kitaguchi, H. Funahashi, T. Nakura, M. Hino, H.M Shimizu, Phys. Rev. A Vol. 67, 033609.

[10] T. Ebisawa, S. Tasaki, et al., Phys. Rev. A, Vol 57, 4720-4729.

[11] T.Ebisawa, D. Yamazaki, S. Tasaki, et al., Phys. Lett. A 259 (1999) 20-24.

[12] S. Tasaki, T. Ebisawa, R. Maruyama, N. Achiwa, T. Kawai, Y. Kawabata, M. Hino, D. Yamazaki, Physica B 335 (2003) 234-237.

[13] D.Yamazaki, NIMA 488 (2002) 623-633

[14] R. Maruyama, S. Tasaki, M. Hino, M. Takeda, T. Ebisawa, Y. Kawabata, NIM A503(2004) 505-512.

[15] M.Hino, M. Kitaguchi, Y. Kawabata, et al., NIM-A, 574 (2007) 292-296.

[16] M. Hino, private communication. 